\title{
Experimental Testing of the New Biomedical Substance of Pig Kidneys for the Treatment of Nephrolithiasis
}

\author{
Aleksandr Yu. Zharikov, PhD, ScD*; Igor P. Saldan, PhD, ScD; \\ Valery I. Kiselev, PhD, ScD; Ganna V. Pavlyashik \\ Altai State Medical University, Barnaul, the Russian Federation
}

\begin{abstract}
The aim of our study was to test anti-lithogenic activity of the new biomedical substance from pig kidneys (PK-BMS) on the experimentally induced nephrolithiasis.

Materials and Methods: The experiments were performed with 30 male Wistar outbred rats weighting 220-280g. The experimental animals were divided into two groups. In the disease-control group (DCG), the animals received a $1 \%$ solution of EG for 6 weeks. The rats in therapy group (TG), beginning from the fourth week, in addition to the daily EG intake, received PK-BMS in the amount of 1.0 per rat. The production of this substance was carried out at Altaivitaminy ZAO (Biysk, Altai Krai, Russia) by the method of cool dehumidification. In daily urine, we determined the concentration of oxalate, phosphate and calcium ions, creatinine excretion every 3 or 4 days in both groups; the activity of LDH, GGT, and NAG was measured every 7 days in the injured kidney epithelium. For the study of free-radical oxidation activity and for morphological examination of animal kidneys, after 6 weeks of the experiment, 5 rats from each group were euthanized. The occurrence of calcium compounds was determined by von Kossa's staining method.

Results: After a 6-week EG intake, we found the typical biochemical and morphological symptoms of experimental nephrolithiasis in rats of DCG: urine supersaturation with oxalate ions, significant increase in the activity of marker enzymes, activation of free-radical oxidation in the kidneys, and formation of calcium deposits in the kidneys. In TG, the new PK-BMS intake resulted in a significant alleviation of the experimental nephrolithiasi: significant decrease in the level of oxalate ions and activity of marker enzymes, reduction of free-radical oxidation in the kidneys, decrease in the number and size of calcium deposits in the area of renal papillae.
\end{abstract}

Conclusion: It was established that during the experimental nephrolithiasis, a three-week intake of the new PK-BMS is accompanied by a significant anti-lithogenic effect. (Int J Biomed. 2017; 7(1):41-45.)

Key Words: experimental nephrolithiasis $\bullet$ anti-lithogenic activity $\bullet$ biomedical substance $\bullet$ pig kidneys

\section{Abbreviations}

CAT, catalase; EG, ethylene glycol; GGT, gamma glutamyl transpeptidase; GPO, glutathione peroxidase; LDH, lactate dehydrogenase; MDA, malondialdehyde; NAG, N-acetyl-beta-D-glucosaminidase; SOD, superoxide dismutase; TAA, total antioxidant activity; TPO, total prooxidant activity; TBRPs, thiobarbiturate-reactive products.

\section{Introduction}

Previous research has shown that the long-term use of the raw material from pig kidneys (PK-RM) results in significant alleviation of experimentally induced nephrolithiasis in rats. ${ }^{[1]}$

*Corresponding author: Prof. Alexander Yu. Zharikov, PhD, $S c D$. Altai State Medical University, Barnaul, the Russian Federation. E-mail: zharikova_y@mail.ru
The typical diagnostic indicators were alleviation of the urine supersaturation with oxalate ions, a significant reduction in the activity of marker enzymes of the injured kidney epithelium, suppression of free-radical oxidation, and significant reduction of the number and size of calcium deposits. ${ }^{[1]}$ These results allowed us to assume that PK-RM can be a very promising source for the development of a new effective anti-lithogenic remedy. 
The aim of our study was to test anti-lithogenic activity of the new biomedical substance from pig kidneys (PK-BMS) on the experimentally induced nephrolithiasis.

\section{Materials and Methods}

The experiments were performed with 30 male Wistar outbred rats weighting 220-280g. The animals were kept in separate cages designed for urine accumulation in the conditions of standard laboratory nutrition. Modeling of nephrolithiasis was made according to the generally accepted ethylene-glycol model: lithogenesis was provoked by the continuous intake of a $1 \%$ solution of EG. ${ }^{[2]}$

The experimental animals were divided into two groups. In the disease-control group (DCG), the animals received a $1 \%$ solution of EG for 6 weeks. The rats in therapy group (TG), beginning from the fourth week, in addition to the daily EG intake, received PK-BMS in the amount of 1.0 per rat. The production of this substance was carried out at Altaivitaminy ZAO (Biysk, Altai Krai, Russia) by the method of cool dehumidification that included the following stages:

1. The preparation of biomaterials: defrosting the raw pig kidneys at room temperature; removing surface fat; homogenizing by the laboratory homogenizer at 10,000 rpm for 5 minutes; weighing and distributing the homogentisate on the calibrated trays as a smooth layer not more than $0.5 \mathrm{~cm}$ thick.

2. Freezing (vitrification) of the product at a temperature of $-45^{\circ} \mathrm{C}$ for 4 hours.

3. Primary drying: drying of the product in the vacuum chamber at a temperature of $-40^{\circ} \mathrm{C}$ and under a pressure of $10 \mathrm{~Pa}$ for 48 hours.

4. Secondary drying: drying of the product at a temperature of $20^{\circ} \mathrm{C}$ for 6 hours.

As a result of the process described, $80 \%$ of the moisture was removed from the biological material while preserving its structural and functional integrity.

In daily urine, we determined the concentration of oxalate, phosphate and calcium ions, creatinine excretion every 3 or 4 days in both groups; the activity of LDH (indicates the level of cell cytolysis), GGT (indicates the level of cellular membrane damage), and NAG (indicates the functional disorders in nephrocytes) was measured every 7 days in the injured kidney epithelium.

The oxalate-ions in the urine were determined by highperformance liquid chromatography in accordance with the methods we developed earlier. ${ }^{[3]}$ The $80 \%$-acetonitrile aqueous solution at gradient from 0 to $100 \%$ and $0.1 \%$ sulphuric acid solution were used as eluents. The eluent feed rate was 100 $\mu \mathrm{l} / \mathrm{min}$, the volume of elution $-1000 \mu \mathrm{l}$, and the temperature of the chromatographic column $-35 \mathrm{C}^{\circ}$. The detection was carried out at $\lambda=210 \mathrm{~nm}$. A calibration curve was built using the standard oxalate ion solution with a concentration of $1 \mathrm{mg} /$ $\mathrm{ml}$ (Fluka Chemicals Ltd). The calculation of phosphate ions was carried out by the method of photo-electric colorimetry at $\lambda=440 \mathrm{~nm}$. The method is based on the reaction of formation of the phosphoric-molybdenic-vanadic complex having a typical yellow color. The calcium ions in the urine were also calculated by photoelectric colorimetry in a reaction with o-cresol-phtalein complexon at $\lambda=590 \mathrm{~nm}$.

The activity of LDH was determined by spectrophotometry at $\lambda=340 \mathrm{~nm}$. This method is based on the pyruvate reduction reaction to lactic acid. This reaction is catalyzed by LDH and its rate is proportional to the enzyme activity. The catalytic activity of GGT, for the calculation of which we used the method of photoelectric colorimetry, was calculated proportionally to the amount of n-nitroaniline, which is formed in the reaction between L- $\gamma$-glutamyl-3carboxy-4-nitroaniline and glycylglycine. The detection of n-nitroaniline was carried out using the photoelectric colorimeter at $\lambda=400 \mathrm{~nm}$. The calculation of NAG was carried out according to the modified Maruch method. ${ }^{[4]}$ According to this method, NAG activity is proportional to the amount of n-nitrophenol, which is formed as a result of the hydrolytic reaction of $\mathrm{n}$-nitro-N-acetyl- $\beta$-glucosamine catalyzed by this enzyme. The measurement of the n-nytrophenol amount was carried out by spectrophotometry at $\lambda=400 \mathrm{~nm}$. The activity of all enzymes was calculated in relation to the urine creatinine concentrations $(\mathrm{mg} / \mathrm{l})$ and was presented in standard units (U/ $\mathrm{mg}$ of creatinine).

For the study of free-radical oxidation activity, which is a significant indicator of lithogenesis, ${ }^{[5,6]}$ and for morphological examination of animal kidneys, after 6 weeks of the experiment, 5 rats from each group were euthanized taking into account the requirements of the World Medical Association Declaration of Helsinki (2000). Free-radical oxidation activity was determined based on the indicators of oxidant/antioxidant status. The indicators of oxidant status were determined in the homogenate of the kidney cortex. The total index of the concentration of all pro-oxidants and free-radical methabolites (TPO) was estimated by the color intensity of the florescent complex, which is formed by the interaction between Tween- 80 peroxidation products and thiobarbituric acid. In addition, we estimated the concentration of MDA and other TBRPs.

The activity of the antioxidant system was studied in the homogenate of kidney cortex. To estimate the antioxidant status in cells, we determined TAA and activity of CAT, SOD and GPO. TAA was estimated by the degree of inhibition of $\mathrm{Fe} 2+/$ ascorbate-induced oxidation of Tween- 80 by the tissue homogenate (erythrocyte hemolysate). CAT activity was estimated by the reduction of the sodium molybdate oxydation by hydrogen peroxide. SOD activity was estimated by the level of nitroformazan, a colored product of nitrotetrazolium reduction by superoxide radicals. The marker of GPO activity was the estimation of unoxidized glutathione in the color reaction with Ellman's reagent.

The morphological study of the rat kidneys was conducted using light-optical microscopy. A 10\% formalin solution was used as a preservative. For the estimation of disorders in the kidney cortex and medulla, the 4-6-micronthick tissue sections were colored by H\&E. On the 10-15-micron-thick sections, the occurrence of calcium compounds was determined by von Kossa's staining method. They were identified as calcium deposits of black color. In this histochemical reaction, the nuclei turn red and the other tissue 
structures turn pink (magnifications are x100 and x400).

The obtained results were statistically processed. ${ }^{[7]}$ The mean (M) and standard error of the mean (SEM) were deduced. The Wilcoxon criterion was used to compare the differences between the paired samples. A probability value of $P<0.05$ was considered statistically significant.

\section{Results and Discussion}

After a 6-week EG intake, we found the typical biochemical and morphological symptoms of experimental nephrolithiasis in rats of DCG: urine supersaturation with oxalate ions, significant increase in the activity of marker enzymes, activation of free-radical oxidation in the kidneys, and formation of calcium deposits in the kidneys. Thus, on the third day of the experiment, the animal urine had already shown a consistently high level of the oxalate-ion concentration, which had been preserved during the whole experiment (Table 1).

Table 1.

Parameters of excretory kidney function in rats of DCG

\begin{tabular}{|c|c|c|c|c|c|}
\hline Days & $\begin{array}{l}\text { Oxalate } \\
(\mathrm{mg} / \mathrm{ml})\end{array}$ & $\begin{array}{c}\text { Phosphate } \\
\text { (mg/ml) }\end{array}$ & $\begin{array}{c}\text { Calcium } \\
(\mu \mathrm{mol} / \mathrm{ml})\end{array}$ & $\begin{array}{l}\text { Diuresis } \\
\text { (ml/day) }\end{array}$ & $\begin{array}{l}\text { Creatinine } \\
(\mathrm{mmol} / \text { day })\end{array}$ \\
\hline \multicolumn{6}{|c|}{ Initial level } \\
\hline & - & $\begin{array}{c}9.1 \pm 0.38 \\
(\mathrm{n}=15)\end{array}$ & $\begin{array}{c}1.8 \pm 0.10 \\
(\mathrm{n}=15)\end{array}$ & $\begin{array}{c}5.3 \pm 0.36 \\
(\mathrm{n}=15)\end{array}$ & $\begin{array}{c}7.1 \pm 0.38 \\
(\mathrm{n}=15)\end{array}$ \\
\hline \multicolumn{6}{|c|}{ Experimental nephrolithiasis } \\
\hline 3 & $\begin{array}{c}1.3 \pm 0.29 * \\
(\mathrm{n}=12)\end{array}$ & $\begin{array}{c}9.0 \pm 0.47 \\
(\mathrm{n}=12)\end{array}$ & $\begin{array}{c}1.9 \pm 0.19 \\
(\mathrm{n}=8)\end{array}$ & $\begin{array}{c}5.9 \pm 0.65 \\
(\mathrm{n}=12)\end{array}$ & $\begin{array}{c}9.3 \pm 0.66^{*} \\
(\mathrm{n}=8)\end{array}$ \\
\hline 7 & $\begin{array}{c}1.2 \pm 0.14^{*} \\
(\mathrm{n}=15)\end{array}$ & $\begin{array}{c}8.0 \pm 0.44 \\
(n=15)\end{array}$ & $\begin{array}{c}1.3 \pm 0.09 * \\
(\mathrm{n}=15)\end{array}$ & $\begin{array}{c}5.4 \pm 0.48 \\
(\mathrm{n}=15)\end{array}$ & $\begin{array}{c}8.5 \pm 0.61 \\
(\mathrm{n}=15)\end{array}$ \\
\hline 10 & $\begin{array}{c}1.3 \pm 0.10^{*} \\
(\mathrm{n}=9)\end{array}$ & $\begin{array}{c}8.5 \pm 0.40 \\
(n=9)\end{array}$ & $\begin{array}{c}\text { Not } \\
\text { determined }\end{array}$ & $\begin{array}{c}6.5 \pm 0.64 \\
(n=9)\end{array}$ & $\begin{array}{c}\text { Not } \\
\text { determined }\end{array}$ \\
\hline 14 & $\begin{array}{c}1.4 \pm 0.13^{*} \\
(\mathrm{n}=15)\end{array}$ & $\begin{array}{c}8.2 \pm 0.33 \\
(n=15)\end{array}$ & $\begin{array}{c}1.6 \pm 0.22 \\
(\mathrm{n}=15)\end{array}$ & $\begin{array}{c}5.9 \pm 0.43 \\
(\mathrm{n}=15)\end{array}$ & $\begin{array}{c}6.3 \pm 0.44 \\
(\mathrm{n}=15)\end{array}$ \\
\hline 17 & $\begin{array}{c}1.1 \pm 0.10^{*} \\
(\mathrm{n}=15)\end{array}$ & $\begin{array}{c}8.1 \pm 0.21 \\
(\mathrm{n}=15)\end{array}$ & $\begin{array}{c}1.9 \pm 0.13 \\
(\mathrm{n}=15)\end{array}$ & $\begin{array}{c}7.7 \pm 0.96^{*} \\
(\mathrm{n}=15)\end{array}$ & $\begin{array}{c}10.9 \pm 0.63 * \\
(\mathrm{n}=15)\end{array}$ \\
\hline 21 & $\begin{array}{c}1.3 \pm 0.13 * \\
(\mathrm{n}=15)\end{array}$ & $\begin{array}{c}7.4 \pm 0.46^{*} \\
(\mathrm{n}=15)\end{array}$ & $\begin{array}{c}1.9 \pm 0.23 \\
(\mathrm{n}=15)\end{array}$ & $\begin{array}{c}6.7 \pm 0.55^{*} \\
(\mathrm{n}=15)\end{array}$ & $\begin{array}{c}7.2 \pm 0.49 \\
(\mathrm{n}=15)\end{array}$ \\
\hline 24 & $\begin{array}{c}1.6 \pm 0.17 * \\
(\mathrm{n}=15)\end{array}$ & $\begin{array}{c}5.9 \pm 0.43 * \\
(\mathrm{n}=15)\end{array}$ & $\begin{array}{c}1.4 \pm 0.14 \\
(\mathrm{n}=15)\end{array}$ & $\begin{array}{c}7.6 \pm 1.41 \\
(n=15)\end{array}$ & $\begin{array}{c}9.2 \pm 0.84 \\
(\mathrm{n}=15)\end{array}$ \\
\hline 28 & $\begin{array}{c}1.6 \pm 0.16^{*} \\
(\mathrm{n}=15)\end{array}$ & $\begin{array}{c}6.2 \pm 0.40^{*} \\
(\mathrm{n}=15)\end{array}$ & $\begin{array}{c}1.5 \pm 0.10 \\
(\mathrm{n}=15)\end{array}$ & $\begin{array}{c}7.7 \pm 0.78^{*} \\
(\mathrm{n}=15)\end{array}$ & $\begin{array}{c}8.6 \pm 1.00 \\
(n=15)\end{array}$ \\
\hline 31 & $\begin{array}{c}1.3 \pm 0.12 * \\
(\mathrm{n}=8)\end{array}$ & $\begin{array}{c}7.9 \pm 0.63 \\
(\mathrm{n}=8)\end{array}$ & $\begin{array}{c}1.5 \pm 0.28 \\
(\mathrm{n}=8)\end{array}$ & $\begin{array}{c}9.4 \pm 1.73 * \\
(\mathrm{n}=8)\end{array}$ & $\begin{array}{c}\text { Not } \\
\text { determined }\end{array}$ \\
\hline 35 & $\begin{array}{c}1.3 \pm 0.12 * \\
(\mathrm{n}=15)\end{array}$ & $\begin{array}{c}6.1 \pm 0.50^{*} \\
(\mathrm{n}=15)\end{array}$ & $\begin{array}{c}1.6 \pm 0.06 \\
(\mathrm{n}=15)\end{array}$ & $\begin{array}{l}8.2 \pm 1.01 * \\
(\mathrm{n}=15)\end{array}$ & $\begin{array}{c}8.4 \pm 0.74 \\
(n=15)\end{array}$ \\
\hline 38 & $\begin{array}{c}1.7 \pm 0.21 * \\
(\mathrm{n}=9)\end{array}$ & $\begin{array}{c}8.2 \pm 0.17 \\
(\mathrm{n}=8)\end{array}$ & $\begin{array}{c}\text { Not } \\
\text { determined }\end{array}$ & $\begin{array}{c}5.6 \pm 0.64 \\
(\mathrm{n}=9)\end{array}$ & $\begin{array}{c}9.8 \pm 0.68^{*} \\
(\mathrm{n}=9)\end{array}$ \\
\hline 42 & $\begin{array}{c}1.3 \pm 0.14^{*} \\
(\mathrm{n}=15)\end{array}$ & $\begin{array}{c}6.2 \pm 0.45^{*} \\
(\mathrm{n}=15)\end{array}$ & $\begin{array}{c}1.6 \pm 0.17 \\
(\mathrm{n}=15)\end{array}$ & $\begin{array}{c}9.0 \pm 1.19 * \\
(\mathrm{n}=15)\end{array}$ & $\begin{array}{c}8.3 \pm 1.03 \\
(\mathrm{n}=14)\end{array}$ \\
\hline
\end{tabular}

* $-P<0.05$ in relation to the initial level

Moreover, DCG rats showed a continuous growth of activity of the marker urine enzymes. By the end of the sixth week of the pathology modeling, LDH activity increased by 2.9 times, GGT - by 1.6 times, and NAG - by 3.8 times $(P<0.001$ vs. the initial levels in all cases) (Table 2).

Table 2.

Enzyme activity in the urine of DCG rats

\begin{tabular}{|c|c|c|c|}
\hline \multirow{2}{*}{ Days } & LDH & GGT & NAG $\left(\times 10^{-3}\right)$ \\
\hline & \multicolumn{3}{|c|}{$\mathrm{U} / \mathrm{mg}$ creatinine per day } \\
\hline \multicolumn{4}{|c|}{ Initial level } \\
\hline & $0.18 \pm 0.015$ & $0.26 \pm 0.015$ & $8.4 \pm 0.32$ \\
\hline \multicolumn{4}{|c|}{ Experimental nephrolithiasis } \\
\hline 7 & $0.32 \pm 0.024$ & $0.30 \pm 0.015$ & $\begin{array}{c}14.4 \pm 2.48 \\
(\mathrm{P}<0.01)\end{array}$ \\
\hline 14 & $\begin{array}{c}0.50 \pm 0.033 \\
(P<0.001)\end{array}$ & $0.32 \pm 0.011$ & $\begin{array}{l}19.4 \pm 1.40 \\
(P<0.001)\end{array}$ \\
\hline 21 & $\begin{array}{c}0.52 \pm 0.032 \\
(P<0.001)\end{array}$ & $0.37 \pm 0.015$ & $\begin{array}{l}20.1 \pm 2.11 \\
(P<0.001)\end{array}$ \\
\hline 28 & $\begin{array}{c}0.44 \pm 0.018 \\
(P<0.001)\end{array}$ & $0.30 \pm 0.010$ & $\begin{array}{l}17.2 \pm 0.90 \\
(P<0.001)\end{array}$ \\
\hline 35 & $\begin{array}{c}0.45 \pm 0.025 \\
(P<0.001)\end{array}$ & $\begin{array}{c}0.42 \pm 0.049 \\
(\mathrm{P}<0.05)\end{array}$ & $\begin{array}{l}15.4 \pm 1.26 \\
(P<0.01)\end{array}$ \\
\hline 42 & $\begin{array}{c}0.53 \pm 0.018 \\
(P<0.001)\end{array}$ & Not determined & $\begin{array}{l}31.9 \pm 2.86 \\
(P<0.001)\end{array}$ \\
\hline
\end{tabular}

$P$ - in relation to the initial level; $n=15$ in all cases.

Simultaneously, we observed a distinct development of oxidative stress in the kidneys of DCG rats (Table 3). Thus, TBRP concentration increased 8.3 times in relation to this index in healthy rats $(\mathrm{P}<0.001)$. At the same time, the activity of GPO, the main antioxidant enzyme, decreased by $7.5 \%$. The most significant evidence of the occurrence of lithogenic processes in the kidneys of DCG rats was the results of morphometry, according to which the number of calcium deposits in the area of renal papillae was $27.4 \pm 3.22$ per field of view and their average size was $12.0 \pm 0.62$ micron.

In TG, we also found the typical biochemical symptoms of nephrolithiasis during the first 3 weeks of the disease modeling (Table 4).

Table 3.

Activity of free-radical oxidation in the kidneys of DCG and TG rats

\begin{tabular}{|c|c|c|c|c|}
\hline $\begin{array}{c}\text { TBRP } \\
(\mu \mathrm{mol})\end{array}$ & $\begin{array}{c}\text { TAS } \\
(\%)\end{array}$ & $\begin{array}{c}\text { CAT } \\
(\%)\end{array}$ & $\begin{array}{c}\text { SOD } \\
(\%)\end{array}$ & $\begin{array}{c}\text { GPO } \\
(\%)\end{array}$ \\
\hline \multicolumn{5}{|c|}{ Healthy rats } \\
\hline $2.9 \pm 0.18$ & $75.5 \pm 2.71$ & $11.9 \pm 0.79$ & $14.9 \pm 1.61$ & $37.4 \pm 1.88$ \\
\hline \multicolumn{5}{|c|}{ DCG } \\
\hline $\begin{array}{c}24.1 \pm 0.62^{*} \\
(P<0.001)\end{array}$ & $78.2 \pm 2.71$ & $13.6 \pm 1.50$ & $11.6 \pm 1.26$ & $\begin{array}{c}29.9 \pm 2.45^{*} \\
(P<0.05)\end{array}$ \\
\hline \multicolumn{5}{|c|}{ TG } \\
\hline $\begin{array}{c}6.5 \pm 0.64 * * \\
(P<0.001)\end{array}$ & $73.0 \pm 2.24$ & $\begin{array}{c}28.5 \pm 2.66^{* *} \\
(P<0.001)\end{array}$ & $\begin{array}{c}23.4 \pm 1.03^{* *} \\
(P<0.01)\end{array}$ & $39.7 \pm 1.80$ \\
\hline
\end{tabular}

*- in relation to the healthy rats; ${ }^{*} *_{-}$in relation to $D C G$ 
Table 4.

Parameters of excretory kidney function in rats of TG

\begin{tabular}{|c|c|c|c|c|c|}
\hline Days & $\begin{array}{l}\text { Oxalate } \\
(\mathrm{mg} / \mathrm{ml})\end{array}$ & $\begin{array}{c}\text { Phosphate } \\
(\mathrm{mg} / \mathrm{ml})\end{array}$ & $\begin{array}{c}\text { Calcium } \\
(\mu \mathrm{mol} / \mathrm{ml})\end{array}$ & $\begin{array}{l}\text { Diuresis } \\
(\mathrm{ml} / \text { day })\end{array}$ & $\begin{array}{l}\text { Creatinine } \\
(\mathrm{mmol} / \text { day })\end{array}$ \\
\hline \multicolumn{6}{|c|}{ Initial level } \\
\hline & - & $\begin{array}{c}9.0 \pm 0.20 \\
(\mathrm{n}=15)\end{array}$ & $\begin{array}{c}2.2 \pm 0.10 \\
(\mathrm{n}=15)\end{array}$ & $\begin{array}{c}4.0 \pm 0.49 \\
(\mathrm{n}=15)\end{array}$ & $\begin{array}{c}5.8 \pm 0.52 \\
(\mathrm{n}=15)\end{array}$ \\
\hline \multicolumn{6}{|c|}{ Experimental nephrolithiasis } \\
\hline 3 & $\begin{array}{c}1.5 \pm 0.13 \\
(\mathrm{n}=15)\end{array}$ & $\begin{array}{c}9.4 \pm 0.91 \\
(\mathrm{n}=13)\end{array}$ & $\begin{array}{c}2.1 \pm 0.18 \\
(\mathrm{n}=15)\end{array}$ & $\begin{array}{c}3.5 \pm 0.56 \\
(\mathrm{n}=15)\end{array}$ & $\begin{array}{c}5.9 \pm 0.54 \\
(\mathrm{n}=15)\end{array}$ \\
\hline 7 & $\begin{array}{c}1.8 \pm 0.19 \\
(\mathrm{n}=11)\end{array}$ & $\begin{array}{c}8.6 \pm 0.20 \\
(\mathrm{n}=12)\end{array}$ & $\begin{array}{c}1.4 \pm 0.13^{*} \\
(\mathrm{n}=15)\end{array}$ & $\begin{array}{c}4.1 \pm 0.16 \\
(n=15)\end{array}$ & $\begin{array}{c}6.5 \pm 0.69 \\
(\mathrm{n}=14)\end{array}$ \\
\hline 10 & $\begin{array}{c}1.6 \pm 0.11 \\
(\mathrm{n}=15)\end{array}$ & $\begin{array}{c}7.6 \pm 0.15 \\
(\mathrm{n}=15)\end{array}$ & $\begin{array}{c}1.8 \pm 0.08^{*} \\
(\mathrm{n}=15)\end{array}$ & $\begin{array}{c}4.3 \pm 0.72 \\
(\mathrm{n}=15)\end{array}$ & $\begin{array}{c}4.9 \pm 0.52 \\
(\mathrm{n}=14)\end{array}$ \\
\hline 14 & $\begin{array}{c}1.6 \pm 0.12 \\
(\mathrm{n}=13)\end{array}$ & $\begin{array}{c}7.7 \pm 0.31 \\
(\mathrm{n}=10)\end{array}$ & $\begin{array}{c}1.8 \pm 0.17 * \\
(\mathrm{n}=12)\end{array}$ & $\begin{array}{c}4.2 \pm 0.73 \\
(n=14)\end{array}$ & $\begin{array}{c}6.6 \pm 0.63 \\
(\mathrm{n}=14)\end{array}$ \\
\hline 17 & $\begin{array}{c}1.4 \pm 0.09 \\
(\mathrm{n}=15)\end{array}$ & $\begin{array}{c}8.3 \pm 0.36 \\
(\mathrm{n}=15)\end{array}$ & $\begin{array}{c}1.5 \pm 0.06^{*} \\
(\mathrm{n}=15)\end{array}$ & $\begin{array}{c}5.3 \pm 0.84 \\
(\mathrm{n}=15)\end{array}$ & $\begin{array}{c}7.2 \pm 0.77 \\
(\mathrm{n}=15)\end{array}$ \\
\hline 21 & $\begin{array}{c}1.5 \pm 0.11 \\
(\mathrm{n}=12)\end{array}$ & $\begin{array}{c}11.3 \pm 0.28^{*} \\
(\mathrm{n}=14)\end{array}$ & $\begin{array}{c}2.0 \pm 0.21 \\
(\mathrm{n}=13)\end{array}$ & $\begin{array}{c}4.1 \pm 0.67 \\
(n=15)\end{array}$ & $\begin{array}{c}7.1 \pm 0.52 \\
(\mathrm{n}=15)\end{array}$ \\
\hline \multicolumn{6}{|c|}{ Treatment with the new PK-BMS } \\
\hline 24 & $\begin{array}{c}1.2 \pm 0.10 \\
(\mathrm{n}=14)\end{array}$ & $\begin{array}{c}11.5 \pm 0.46^{*} \\
(\mathrm{n}=14)\end{array}$ & $\begin{array}{c}1.1 \pm 0.05^{*} \\
(\mathrm{n}=14)\end{array}$ & $\begin{array}{c}4.5 \pm 0.64 \\
(\mathrm{n}=14)\end{array}$ & $\begin{array}{c}6.4 \pm 0.78 \\
(n=14)\end{array}$ \\
\hline 28 & $\begin{array}{c}1.0 \pm 0.07 \\
(\mathrm{n}=14)\end{array}$ & $\begin{array}{c}10.8 \pm 0.40 * \\
(\mathrm{n}=14)\end{array}$ & $\begin{array}{c}2.4 \pm 0.16 \\
(\mathrm{n}=14)\end{array}$ & $\begin{array}{c}5.9 \pm 0.93 \\
(\mathrm{n}=14)\end{array}$ & $\begin{array}{c}8.3 \pm 0.95^{*} \\
(\mathrm{n}=14)\end{array}$ \\
\hline 31 & $\begin{array}{c}1.1 \pm 0.09 \\
(\mathrm{n}=15)\end{array}$ & $\begin{array}{c}11.2 \pm 0.38 * \\
(\mathrm{n}=15)\end{array}$ & $\begin{array}{c}1.6 \pm 0.06^{*} \\
(\mathrm{n}=15)\end{array}$ & $\begin{array}{c}4.7 \pm 0.69 \\
(n=15)\end{array}$ & $\begin{array}{c}6.4 \pm 0.92 \\
(\mathrm{n}=15)\end{array}$ \\
\hline 35 & $\begin{array}{c}1.1 \pm 0.05 \\
(\mathrm{n}=14)\end{array}$ & $\begin{array}{c}11.4 \pm 0.32 * \\
(\mathrm{n}=15)\end{array}$ & $\begin{array}{c}1.5 \pm 0.09^{*} \\
(\mathrm{n}=15)\end{array}$ & $\begin{array}{c}4.8 \pm 0.39 \\
(n=15)\end{array}$ & $\begin{array}{c}7.1 \pm 0.63 \\
(\mathrm{n}=15)\end{array}$ \\
\hline 38 & $\begin{array}{c}0.9 \pm 0.07 \\
(\mathrm{n}=12)\end{array}$ & $\begin{array}{c}11.5 \pm 0.34 * \\
(\mathrm{n}=15)\end{array}$ & $\begin{array}{c}1.2 \pm 0.06^{*} \\
(\mathrm{n}=15)\end{array}$ & $\begin{array}{c}5.4 \pm 0.73 \\
(\mathrm{n}=15)\end{array}$ & $\begin{array}{c}7.8 \pm 0.90 \\
(\mathrm{n}=15)\end{array}$ \\
\hline 42 & $\begin{array}{c}1.0 \pm 0.08 \\
(\mathrm{n}=15)\end{array}$ & $\begin{array}{c}11.2 \pm 0.41 * \\
(\mathrm{n}=15)\end{array}$ & $\begin{array}{c}1.3 \pm 0.06^{*} \\
(\mathrm{n}=15)\end{array}$ & $\begin{array}{c}5.2 \pm 0.83 \\
(\mathrm{n}=15)\end{array}$ & $\begin{array}{c}7.3 \pm 0.84 \\
(\mathrm{n}=15)\end{array}$ \\
\hline
\end{tabular}

$*_{-} P<0.05$ in relation to the initial level

These symptoms included urine supersaturation with oxalate ions and an increase of fermenturia that led to increased levels of LDH- and NAG activity in the urine by 2.1 and 1.6 times, respectively $(P<0.001$ in both cases). Nevertheless, the new PK-BMS intake resulted in a significant alleviation of the experimental nephrolithiasis (Table 4). Thus, the level of oxalate ions in the urine decreased by 1.3-1.5 times in relation to the 21 st-day level. In addition, the urine enzyme activity significantly decreased, and by the end of the experiment, LDH activity was 2.1 lower than on the initial level. The same dynamics were observed in relation to NAG activity (Table 5). Furthermore, we discovered significant changes in the development of oxidative stress in the kidney tissue. By the end of the course of intake of the new biomedical substance from pig kidneys, the concentration of TBRP decreased compared to DCG by 3.7 times $(P<0.001)$, while the activity of all antioxidant enzymes increased significantly compared to their levels in DCG and healthy animals (Table 5). Finally, according to the results of morphometry, the number of calcium deposits forming in the area of renal papillae of the treated rats decreased by 12.5 times (from $27.4 \pm 3.22$ to $2.2 \pm 2.00$ per field of view) in comparison with DCG, and their average size decreased by 3.2 times (from $12.0 \pm 0.62 \mu \mathrm{m}$ to $3.7 \pm 3.55 \mu \mathrm{m} ; P<0.001)$.

Table 5.

Enzyme activity in the urine of TG rats

\begin{tabular}{|c|c|c|c|}
\hline \multirow{2}{*}{ Days } & $\mathrm{LDH}$ & GGT & NAG $\left(\times 10^{-3}\right)$ \\
\hline & \multicolumn{3}{|c|}{ U/mg creatinine per day } \\
\hline \multicolumn{4}{|c|}{ Initial level } \\
\hline & $\begin{array}{c}0.21 \pm 0.023 \\
(n=11)\end{array}$ & $\begin{array}{c}0.33 \pm 0.015 \\
(\mathrm{n}=10)\end{array}$ & $\begin{array}{c}9.8 \pm 0.46 \\
(n=15)\end{array}$ \\
\hline \multicolumn{4}{|c|}{ Experimental nephrolithiasis } \\
\hline 7 & $\begin{array}{c}0.35 \pm 0.025 \\
(\mathrm{n}=14)\end{array}$ & $\begin{array}{c}0.36 \pm 0.015 \\
(\mathrm{n}=14)\end{array}$ & $\begin{array}{c}10.5 \pm 0.48 \\
(\mathrm{n}=14)\end{array}$ \\
\hline 14 & $\begin{array}{c}0.44 \pm 0.034 \\
(\mathrm{n}=14)\end{array}$ & $\begin{array}{c}0.42 \pm 0.014 \\
(\mathrm{n}=14)\end{array}$ & $\begin{array}{c}15.3 \pm 0.97 \\
(\mathrm{n}=14)\end{array}$ \\
\hline 21 & $\begin{array}{c}0.45 \pm 0.013 \\
(P<0.001 ; \mathrm{n}=13)\end{array}$ & $\begin{array}{c}0.36 \pm 0.011 \\
(\mathrm{n}=8)\end{array}$ & Not determined \\
\hline \multicolumn{4}{|c|}{ Treatment with the new PK-BMS } \\
\hline 28 & $\begin{array}{c}0.36 \pm 0.020 \\
(\mathrm{n}=14)\end{array}$ & $\begin{array}{c}0.38 \pm 0.016 \\
(\mathrm{n}=14)\end{array}$ & $\begin{array}{c}7.3 \pm 0.33 \\
(\mathrm{n}=14)\end{array}$ \\
\hline 35 & $\begin{array}{c}0.09 \pm 0.014 \\
(P<0.001 ; \mathrm{n}=15)\end{array}$ & $\begin{array}{c}0.36 \pm 0.018 \\
\quad(\mathrm{n}=13)\end{array}$ & $\begin{array}{c}6.5 \pm 0.52 \\
(\mathrm{n}=15)\end{array}$ \\
\hline 42 & $\begin{array}{c}0.10 \pm 0.008 \\
(P<0.001 ; \mathrm{n}=15)\end{array}$ & $\begin{array}{c}0.37 \pm 0.013 \\
\quad(\mathrm{n}=14)\end{array}$ & $\begin{array}{c}8.5 \pm 0.37 \\
(\mathrm{n}=15)\end{array}$ \\
\hline
\end{tabular}

$P$ - in relation to the initial level

Thus, the obtained results during the conducted experiments demonstrated that the new PK-BMS had a high anti-lithogenic activity. Also, it should be noted that there is a multipurpose nature of the therapeutic effect of this substance at experimental nephrolithiasis. Such components of oxalate nephrolithiasis pathogenesis as oxidative stress in kidney tissue, damage of urothelium, urine supersaturation with lithogenic ions and crystallization of renal concrements can also be the targets for correction. All of these resulted in a significant decrease of the number and sizes of calcium deposits in the kidneys of experimental rats.

It is entirely possible that the multipurpose effect of the new PK-BMS is determined by the complex of its biomedical properties depending on the organic structure of pig kidneys. The research of these properties and the search for the active ingredient of this substance will be the object of our further investigations. Currently, with some certainty it is possible to suppose that the technological processing of pig kidney tissues using the gentle methods does not decrease their antilithogenic activity, which creates favorable conditions for the development of the optimized technological production scheme for the new anti-lithogenic drugs.

In conclusion, it was established that during the experimental nephrolithiasis, a three-week intake of the new biomedical substance from pig kidneys is accompanied by a significant anti-lithogenic effect equal to the raw material from pig kidneys. 


\section{Competing interests}

The authors declare that they have no competing interests.

\section{Sources of funding}

This study was funded by the Federal State Budgetary Educational Institution of Higher Professional Education "Altai State Medical University" of the Ministry of Health of the Russian Federation.

\section{References}

1. Bryukhanov VM, Zharikov AYu, Zverev YaF, Lampatov VV, Azarova OV, Talalaeva OS, et al. The experience of application of raw material from pork kidneys in pharmacological correction of experimental nephrolithiasis. Bulletin SB RAMS. 2011;31(3):97-103. [Article in Russian]. 2. Zharikov AYu, Bryukhanov VM, Zverev YaF, Lampatov
VV. Modern methods of oxalate's nephrolithiasis modeling. Nephrology. 2008;12(4):33-6. [Article in Russian].

3. Zharikov AYu, Lampatov VV, Zverev YaF, Bryukhanov VM, Kudinov AV. A new technique for urinary oxalate ion determination. Klin Lab Diag. 2010;12:3-5.[Article in Russian]. 4. Maruhn D. Rapid colorimetric assay of beta-galactosidase and N-acetyl-beta-glucosaminidase in human urine. Clin Chim Acta. 1976;73(3):453-61.

5. Zharikov AYu, Zverev YaF, Brukhanov VM, Lampatov VV. Mechanism of formation of crystals in oxalate nephrolithiasis. Nephrology. 2009;13(4):37-50. [Article in Russian].

6. Zverev YaF, Bryukhanov VM, Talalaeva OS, Lampatov VV, Zharikov AYu, Talalaev SV, et al. On the role of processes of free radical oxidation in the development of experimental nephrolithiasis. Nephrology. 2008;12(1):58-63. [Article in Russian].

7. Khafaziyanova RCh, Burykin IM, Aleeva GN Mathematical statistic in experimental and clinical pharmacology. Kazan: Medicine; 2006. 